\title{
Use and Utilization of Performance Information in Hungary: Exemplary Cases from the Local- Government and the Higher-Education Sectors ${ }^{1}$
}

György Hajnal, Márton Ugrósdy

\begin{abstract}
Performance information and performance management are usually seen as tools to promote the efficiency and effectiveness of different public-policy programs. Performance management is a hot topic in the post-NPM discourse, however most of the debate is centered on the Western European and Anglo-Saxon models of measurement and evaluation of public services. This paper examines how a Central European country with a strong Rechtsstaat tradition can adapt to the use of performance management, and what patterns we can identify in the actual manifestations of measurement and use of data. The authors argue that even though performance management is not known in Hungary as per defined in the academic literature, there are signs on the ground that PM ideology and actual use are gaining traction in every field of public services, both in central and local governments.
\end{abstract}

\section{Keywords:}

performance management, public-administration reform, local-government reform, government agency.

\section{Introduction}

Performance management or any method that leads to a more efficient use of public resources has always been a priority in public-sector reforms. Knowledge about performance management can either originate in policy transfer, when working (or perceivably working) methods are adapted from other settings, while the other source can be indigenous innovation.

1 This work was supported by the COST Action IS1207, "Local Public Sector Reforms (LocRef)". 
International and national policy transfer can be related to the adoption of different performance-management practices. Policy transfer is not uncommon in the Central and Eastern European (CEE) countries, as the accession to the European Union provided a coercive framework for most institutional reforms, and enlargement countries had to adapt large sections of the acquis communautaire (see also Nemec and Sagat 2011). This, combined with the dependency of the CEE countries on EU funds, leads to a weakening of the individual policy-making capacities of these governments (Bartlett 2013, 2), making policy transfer an appealing source for new management practices.

Bartlett argues that throughout the CEE region the effects of the economic crisis highlighted the need for better policy-making and better ex-ante and ex-post evaluations of different policy options (Bartlett 2013, 17). This leitmotif is clearly visible in the motivations of local governments (LGs): as their operating environment is constantly changing and their funds are shrinking, they grow particularly sensible to the success or failure of their activities, which reinforces the role of regular performance measurements.

The 2008 financial crisis underscored the need for better policy-making, a better understanding of economic and social problems (Bartlett 2013, 17) and eased external coercive pressures from international organizations (European Commission, International Monetary Fund, OECD, for example) therefore national and sub-national actors - theoretically - can have a chance to establish their own administrative capacity for independent policy-making and performance management (ibid., 2), as the credibility and capacities of these international organizations to effectively handle the effects of the crisis were questioned. This underscores the role of indigenous innovation, which is often overlooked as policy transfer was often seen as the main tool to drive public-sector reforms. Preliminary information from the field also supports the view that it is not only transfer but also internal pressures (let them be financial, legislative or personal) that can prompt changes, even in Rechtsstaat-type administrative cultures, which are thought to be less prone to innovation.

Having established that performance management exists in Central and Eastern Europe, we also have to deal with the risks associated with these measurement systems. As Nemec and Sagat underscore: PM is a highly complex system which is not so simple to implement or adapt. This has two core aspects: one is that CEE countries have limited policy-making and -implementation capacities, the second is that regional, cultural and administrative traditions (limited competition, legal uncertainty, etc.) hinders the success of PM implementation (Nemec and Sagat 2011, 11). Staronova (2005) warns of the limited availability of existing data and the missing capacity to process them. Staronova (2009) also highlights that policy-making in Central Europe is rather a legalistic exercise than a real policy process; therefore it is often hard to adapt Western, management-oriented concepts to the local context. 
Hajnal and Jenei (2008) argue that Hungarian public administration is in a very delicate situation, facing pressures from two distinct directions: on the one hand, people are losing confidence in institutions while there are constant calls for more participation and direct democracy. Public administration's credibility is being constantly challenged. Furthermore, there are day-to-day tensions between legalism and managerialism (ibid., 217), which makes management-oriented approaches very vulnerable to misperception. Mistrust in public institutions, politicoadministrative conflicts as well as the (administrative) law-centered approach of the central and local government creates an inhospitable environment for publicmanagement approaches. The concept of Public Management cannot be transferred without problems to the Central European context (ibid., 219).

In our research, we set out to examine whether PM permeated public policymaking on the national and local levels in Hungary, which can be categorized - according to Kuhlmann and Wollmann (2014) - as a country of the Central Eastern European Model. Available, largely sporadic performance data in the Hungarian public administration are frequently inconsistent, depending on the organization producing them and on the planned use of the data. There are a few central-government agencies possessing data of relatively high quality; on the other hand many if not most LGs do not even know about the possibility of measuring performance, let alone what to and how to measure it.

\subsection{Conceptual and theoretical framework}

In the following we present the main concepts and models of performance management and see whether it can be applied to the Central Eastern European region.

To define performance, we follow Pollitt and Bouckaert who claim that:

Performance is commonly conceived in either individual, or organisational terms, and also as a combination of both. It may also be identified with an activity, programme or policy (Talbot 2005a), the latter linking in with the evaluation movement. Talbot (2005a) outlines the different dimensions of performance - as accountability; user choice; customer service; efficiency; results and effectiveness; resource allocation; and creating public value. 'Performance' is also commonly used as prefatory to other activities such as auditing and budgeting and more diffusely to 'improvement', 'orientation' and 'trajectories' (Pollitt and Bouckaert 2004, 126, 341, cited by Bouckaert and Halligan 2008, 15).

Van Dooren et al. define performance management as "a type of management that incorporates and uses performance information for decision-making" (van Dooren et al. 2010, 30). Incorporation and use are the key words, as performance measurement remains ineffective as far as its results are not used in the policy cycle. 
Bouckaert and Halligan (2008) identify four ideal types of performance management (PM), which they label (a) performance administration, (b) management of performances, (c) performance management (the ideal type) ${ }^{2}$ and (d) performance governance. A pre-performance-management state exists, as well, where performance information is not used to influence policies. The five types - which follow each other in their sophistication) - can be identified as follows:

1. Pre-performance stage: measurement is intuitive and subjective, data is not incorporated into decision-making, there is no use of the existing data, and there is a widespread functional unawareness;

2. Performance administration measures inputs and sometimes the process as well, the use of data is limited, and used only for single-loop learning;

3. Management of performances has specialized performance-measurement systems, but usage is disconnected, and there is a serious incoherence in the management system;

4. Performance management (it) has hierarchical measurement systems, which internally integrate data to the input side of policy decisions, while the use of data is consistent and coherent;

5. Performance governance is the final ideal type, where there is a consolidated measurement system, where data is used societally as well.

Table 1 summarizes the most important features of the three ideal types which are relevant for our current study. We will use performance administration, management of performances and performance management (it) to measure the development of different Hungarian performance-management regimes.

2 To clarify our terminology, from now on we will use performance management for the whole concept of using some kind of data to support decisions and policy-making, while the ideal type will be labeled performance management (it) to avoid confusion. 


\section{Table 1}

The characteristics of three ideal types of performance management

(Bouckaert and Halligan 2008, 76, 98, 125)

\begin{tabular}{|c|c|c|c|}
\hline Ideal type features & $\begin{array}{l}\text { Performance } \\
\text { administration }\end{array}$ & $\begin{array}{l}\text { Management of } \\
\text { performances }\end{array}$ & $\begin{array}{c}\text { Performance } \\
\text { management (it) }\end{array}$ \\
\hline \multicolumn{4}{|c|}{ Measurement } \\
\hline $\begin{array}{l}\text { Type of } \\
\text { measurement }\end{array}$ & $\begin{array}{l}\text { mechanistic and } \\
\text { closed }\end{array}$ & $\begin{array}{l}\text { internally interactive and } \\
\text { closed }\end{array}$ & $\begin{array}{l}\text { internally interactive and } \\
\text { open }\end{array}$ \\
\hline $\begin{array}{l}\text { Design of } \\
\text { measurement } \\
\text { system }\end{array}$ & $\begin{array}{l}\text { ad-hoc schemes } \\
\text { by internals }\end{array}$ & $\begin{array}{l}\text { organized by } \\
\text { management function, } \\
\text { standard schemes } \\
\text { developed by staff and } \\
\text { consultants }\end{array}$ & $\begin{array}{l}\text { imported standard } \\
\text { models (benchmarking) } \\
\text { by staff and consultants }\end{array}$ \\
\hline $\begin{array}{l}\text { Span of } \\
\text { measurement }\end{array}$ & $\begin{array}{l}\text { limited and } \\
\text { selective; } \\
\text { efficiency and } \\
\text { productivity }\end{array}$ & $\begin{array}{l}\text { organizationally } \\
\text { determined, } \\
\text { economy, efficiency } \\
\text { and effectiveness, } \\
\text { input-activity-output- } \\
\text { effect/outcome }\end{array}$ & $\begin{array}{l}\text { Organization- and } \\
\text { policy-based; economy } \\
\text { efficiency and } \\
\text { effectiveness, input- } \\
\text { activity-output/effect- } \\
\text { outcome }\end{array}$ \\
\hline $\begin{array}{l}\text { Depth of } \\
\text { measurement }\end{array}$ & $\begin{array}{l}\text { micro, single } \\
\text { organizations }\end{array}$ & micro and meso & micro and meso \\
\hline $\begin{array}{l}\text { Criteria of } \\
\text { indicators }\end{array}$ & $\begin{array}{l}\text { technical (valid } \\
\text { and reliable) }\end{array}$ & technical and functional & $\begin{array}{l}\text { technical, functional and } \\
\text { internally legitimate }\end{array}$ \\
\hline $\begin{array}{l}\text { Specific dimension } \\
\text { of measurement }\end{array}$ & $\begin{array}{l}\text { quantitative, } \\
\text { quality is } \\
\text { considered to be } \\
\text { constant }\end{array}$ & $\begin{array}{l}\text { quality requires separate } \\
\text { focus }\end{array}$ & $\begin{array}{l}\text { quality gets integrated } \\
\text { focus }\end{array}$ \\
\hline $\begin{array}{l}\text { Dysfunctionalities } \\
\text { of measuring }\end{array}$ & $\begin{array}{l}\text { no awareness of } \\
\text { pathologies }\end{array}$ & $\begin{array}{l}\text { starting concern for } \\
\text { pathologies }\end{array}$ & $\begin{array}{l}\text { systemic reactive focus } \\
\text { on pathologies }\end{array}$ \\
\hline \multicolumn{4}{|c|}{ Incorporation } \\
\hline $\begin{array}{l}\text { Level of } \\
\text { incorporation }\end{array}$ & static & comparative static & dynamic \\
\hline $\begin{array}{l}\text { Degree of } \\
\text { incorporation }\end{array}$ & $\begin{array}{l}\text { disconnected, } \\
\text { isolated and } \\
\text { ad-hoc }\end{array}$ & $\begin{array}{l}\text { connected per } \\
\text { management function, } \\
\text { not consolidated }\end{array}$ & internally consolidated \\
\hline \multicolumn{4}{|c|}{ Use } \\
\hline General use & $\begin{array}{l}\text { limited and } \\
\text { technical }\end{array}$ & $\begin{array}{l}\text { disconnected policy and } \\
\text { management cycles }\end{array}$ & $\begin{array}{l}\text { integrated policy and } \\
\text { management cycles }\end{array}$ \\
\hline $\begin{array}{l}\text { Main reporting } \\
\text { focus }\end{array}$ & $\begin{array}{l}\text { internal } \\
\text { hierarchy }\end{array}$ & $\begin{array}{l}\text { internal managerial } \\
\text { functions }\end{array}$ & $\begin{array}{l}\text { internal management, } \\
\text { external political }\end{array}$ \\
\hline $\begin{array}{l}\text { Learning by using } \\
\text { (standards) }\end{array}$ & $\begin{array}{l}\text { single-loop } \\
\text { learning }\end{array}$ & $\begin{array}{l}\text { single loops and separate } \\
\text { double loops }\end{array}$ & $\begin{array}{l}\text { single and integrated } \\
\text { double loop }\end{array}$ \\
\hline $\begin{array}{l}\text { Accountability of } \\
\text { performance }\end{array}$ & administrative & managerial & managerial and political \\
\hline $\begin{array}{l}\text { Potential } \\
\text { value added of } \\
\text { performance }\end{array}$ & limited & $\begin{array}{l}\text { Single-management } \\
\text { function improvement }\end{array}$ & integrated development \\
\hline $\begin{array}{l}\text { Potential } \\
\text { dysfunctions of } \\
\text { performance }\end{array}$ & $\begin{array}{l}\text { unawareness } \\
\text { of major } \\
\text { dysfunctions }\end{array}$ & $\begin{array}{l}\text { suboptimal and } \\
\text { incoherent information }\end{array}$ & $\begin{array}{l}\text { negative cost-benefit } \\
\text { analysis }\end{array}$ \\
\hline
\end{tabular}


There are several possible ways of utilizing performance data. One of the most basic ways to handle available information is incorporating it into decision-making, but not in a concise, institutionalized way. Using performance data constitutes the next step, where information is not only available and incorporated, but formal mechanisms also exist to channel these pieces of information into decisions. At this stage, performance measurement is institutionalized (Bouckaert and Halligan 2008, $28-32)$. These ideal types

describe three stages of an intellectual evolution from a dispersed and ad hoc pattern of performance-related activities to a fully fledged and integrated model of Performance Management (ibid., 69).

This is why we perceive these ideal types to form a sequential logical order, according to which performance management can develop.

\subsection{Background: The state of the art in performance management in Hungary}

Using data to support policy decisions is not common in Hungary, even though the legal framework would require regular calculations and measurement. In the following section we will detail how two policy instruments ([regulatory] impact assessment (RIA) and performance management) are gaining ground in the country.

Although ex-ante impact assessment has been a legally defined, compulsory element of the law-making process since 1987 practically hardly any serious impact assessments were prepared in the period up to 2010, when the earlier law was replaced by a new legal framework. In other words, impact assessments - both ex ante and ex post - remained overwhelmingly absent or, if present, largely symbolic throughout the 1990-2010 period. An important exception from this general pattern were the institutions and policies related to the implementation of EU-funded development projects, where systematic - though, for most of the time, relatively low-quality or even symbolic - impact assessments and evaluations formed regular components of EU-funded development programs.

The legislative framework of impact assessment changed in 2010: the 2010/130 Law on law-making introduced a new procedural and regulatory framework on ex-ante and ex-post impact assessment. Interestingly enough, the new regulation moved the framework towards being even more formal and symbolic than it had been earlier. Most importantly, the scope of obligation to produce such assessment remained unspecified, and the same is true for the level of detail and the method used (N.B. that even the concept of impact assessment and evaluation remained undefined). Moreover the symbolic nature of the regulation is signaled by the fact that no monitoring and no sanctioning mechanisms aimed at enforcing the implementation of the new framework were introduced. 
According to the "Rechtsstaat" tradition - exerting a significant impact on Hungary's administrative culture and policy machinery (Hajnal and Jenei 2008) law-making and policy decisions are primarily seen as an abstract legislative exercise (Staronova 2009, 249), while efficiency is still regarded as second to legal formalism (Radaelli 2005, 11, cited by Staronova 2006, 10). In addition to these cultural traits, presumably there are several, more practical factors hindering the increased reliance on PM in the Hungarian public administration:

- The unplanned, short-term-oriented, arbitrary and discretionary nature as well as the informality and 'opacity' of policy/decision making (both in the central and in the local government organizations) eliminates the significance of evidence, including performance data.

- Not only the demand but also the supply side is weak: there are very few experts with adequate expertise, and PA training and education continues to emphasize legal, as opposed to managerial or policy related, topics and approaches (Hajnal 2003).

The frequent organizational and personnel changes in public administration further hindered the use of performance data. The constant reshuffling of government agencies, the high percentage of personnel turnover and the deepening politicization of the public administration makes the establishment of a professional, analytical organization a significant challenge. The structure of the government does not support the establishment of internal "think tanks", while the support of the civil society is rejected (Staronova and Gajduschek 2013, 124). The Rechtsstaat tradition works against any government think tank that would apply scientific standards and international benchmarking for the Hungarian public administration (for details, see Hajnal and Gajduschek 2010, ch. 4). However if we look at the official government policy (KIM 2012), PM and RIA should gain prominence in the future.

As a general observation we emphasize that, throughout the post-1990 decades, performance measurement and, especially, performance management remained a marginal, hardly noticeable issue in public-administration scholarship as well as in the general public-administration reform practice in Hungary. Although some elements - most of all, individual performance appraisal of civil servants - appear with some frequency in practitioner and academic discourses organizational or policy-level measurement, let alone management, of performance remains almost entirely absent (for an overview of central government reform measures, see Hajnal 2006).

Performance management in the local governmental context is one of the (even) less cultivated elements of the performance agenda. Most practical efforts as well as scholarship in this area is concentrated on the measurement/benchmarking of specific service areas (such as water and other utilities as well as various human public services). 
On the local level, in the pre-EU accession phase some LGs introduced certain performance-related elements into their budget format (Hajnal 2008, cited by Kuhlmann and Wollmann 2014, 239); however, initial results were ambiguous, and the use of PM data remained irregular. So far, we were not able to locate systematic and published/publicly available efforts at measuring the performance of internal local governmental processes. Nevertheless, building on the evidence from preliminary interviews (Hajnal and Ugrósdy 2015) we can observe a growing interest in this area, mostly because of the gap between the compulsory roles and the decreasing funding of different government functions (for the effects on local governments, see Hajnal and Rosta 2014), as efficiency becomes more important to make ends achievable.

\subsection{Research questions}

To address the dilemmas mentioned in the previous section, we have produced two main research questions:

1. [RQ1 - Measurement of performance] What kind of performance measurement systems (if any) have appeared in the Hungarian public-policy sector in terms of the functions, processes and data measured?

2. [RQ2 - Use of performance data] Is there any use of the previously gathered performance information? Controlling seems a quite obvious answer, but we touch upon other uses, like program planning, budgeting, incentives, accountability/control and learning/improvement.

\subsection{Method and data}

Our comparative case study describes and compares performance management in the case of a central-government agency (Case 1) and of a municipal self-government (Case 2). The unit of analysis is the organization itself. We have chosen these cases as exemplary cases: even though they both operate in an environment hostile to management practices, they both evolved some kind of functioning PM practice. The two organizations are very different in many regards, but what connects them is their access to performance data and their leaders' interest to use them. Naturally, the quality and quantity of data is highly different in the two cases; this is why we think that studying them will shed light on the evolution of PM in Hungary. That is, the case selection was based on "theoretical sampling" (as opposed to a "typical case") (Yin 2009), whereby we consciously sought to select organizations that are different in many respects but similar in their key outcome: the existence of (some sort of) a performance-management system proper, which clearly differentiates them from the majority of public administration organizations in Hungary. This sampling allows us to study the different (sets of) conditions possibly leading to the creation and operation of performance management. Furthermore, the comparative design allows us to examine the role of the use and incorporation of 
performance data, which is supposed to "make sense" of performance information for the decision-makers.

We have conducted semi-structured interviews with different sources, aiming to gain a comprehensive picture of currently existing PM practices. Every interviewee was asked the same questions, the sessions lasted 30-60 minutes each. Altogether 15 people were interviewed for this study. Questions concentrated on the dimensions of Table 1 and the possible manifestations of the attributes of the ideal types in the Hungarian setting.

Regarding the scoring of different PM regimes in Hungary, we decided to classify individual aspects of the PM regime (measurement, incorporation, use) according to the ideal types of Bouckaert and Halligan (for the complete set of criteria of Performance Administration, consult Bouckaert and Halligan 2008, 71-74; for Managements of Performances, see ibid., 78-97, and for Performance Management (it), ibid., 100-110). We established from the interviews whether the PM regime described by the interlocutors are consistent with the ideal types (or whether there are some segments which are consistent). Interviews were designed to gather information especially on these aspects.

All interviews were conducted between January and March 2015 at the different interviewees' offices in Hungary. All of the interlocutors were glad to share their thoughts, even though sometimes the concept and meaning of performance management was "translated" into everyday terms.

We have combined the interview data with available documents, which were either found on the Internet or provided by the interviewees themselves. Content analysis was conducted on the texts, using MaxQDA to find common patterns across the two cases. This was applied for the development of PM practices and the possible sources of knowledge, as well.

Our sources in Case 1 include the director of the higher-education department within the Education Authority (Source 1A), who is responsible for the daily management of the online system and administering it. We interviewed the information providers, represented by two vice rectors for education at two prominent Hungarian universities (Source 1B and 1C), and the president of the Higher Education Funding Council Hungary, who is supposed to use higher education performance data (Source 1D).

For Case 2 we interviewed the mayor of the town (Source 2A), the director of Városgondozás Eger Kft (Source 2B), two mid-level managers from Városgondozás Eger (Sources 2C and 2D) and the manager of the waste-collection company (Source 2E). We interviewed other experts of the local government arena, such as the president of the National Association of Local Governments (Települési Önkormányzatok Országos Szövetsége - TÖOSZ) (Source 2F), and the secretary general of TÖOSZ (Source 2G). 
We chose the case of Eger, a relatively well-off town in Northern Hungary. Eger has about 40,000 inhabitants, a sound economic base, boasts a college and theatre, has good infrastructure and is the administrative center of its respective county. Eger is making serious efforts to apply performance management to public services; therefore it can be considered an exemplary case.

Over the past few years a very broad range of LGs' responsibilities changed or even disappeared. Therefore we focus on one of the most stable sets of activities: the provision of public services. Eger has its own, local government-owned urban-services company (Városgondozás Eger Kft), which operates various services to maintain the town. Its responsibilities include:

- maintenance of public parks

- street cleaning

- cemetery services

- maintaining rain drains and ditches

- maintenance of public statues and fountains

- providing lighting for the streets

- road maintenance

A separate department within the company is responsible for waste collection and disposal. ${ }^{3}$

As we will detail later, Eger is facing severe budgetary cutbacks, as many of the local government's responsibilities were relocated to different, deconcentrated central-government organizations. Efficiency therefore gained a prominent role in the town, where the mayor is spearheading the efforts for better management. Eger is an exemplary case for performance management in the field of local governments, which is why we included it in this comparative case study.

\section{Case 1: Higher education}

\subsection{Background}

We have chosen a central-government agency, the Education Authority (Oktatási Hivatal), which is responsible for the administration, reporting and planning on both public and higher education in the country. The Education Authority spent more than 1.5 million Euros ${ }^{4}$ of European Union funds to establish the Higher Education Information System (Felsőoktatási Információs Rendszer - FIR), which is the official database for every higher-education institution (including up-to-date budgetary data, staff data and training programs), as well as for every student. All

3 http://varosgondozaseger.hu/ (last accessed 18 April 2015).

4 http://www.oktatas.hu/kozneveles/projektek/ekop1a108_kozig_szolg_elektronizalas (last accessed 18 April 2015). 
of the data is updated and controlled on a daily basis, and it is available for both the higher-education institutions and the policy community, as well.

This online system is clearly capable of administering the performance of the Hungarian higher-education sector, as it contains a quite comprehensive set of data, ranging from budgetary information to the number of diplomas issued.

Even though Hungary has 67 higher-education institutions, which seems a large number compared to the about 10 million inhabitants of the country, most of the students and staff (and therefore funds) are concentrated in a few large public universities. Currently, approximately 300,000 students are studying in the highereducation institutions, but only about 10 percent of them attend private or religious institutions (National Statistics Office 2014). The number of public institutions is 29 , accounting for about 90 percent of students and allocated funds. Therefore the role of government control, planning and monitoring could have a significant effect on the performance of Hungarian higher education, as changing regulations in the state-controlled institutions impact about 85-90 percent of the whole university and college population. This highlights the importance and possible use of the sector's central performance-data system, the FIR. The Law on Higher Education clearly defines the data to be collected, the scope of data collection being very comprehensive. Officially, these data serve as the official background for higher-education budgeting on the national level. The FIR system is regulated by Law CCIV/2011 on Higher Education, as well as the 79/2006 (IV. 5.) Government Decree on the execution of the CXXXIX/2005 Law on Higher Education.

FIR contains the following data:

- data on each training program in the country (study paths, number and classification of lecturers, etc.)

- the current and past status(es) of every student (enrolled, dropout, etc.)

- data on the employees, including their diplomas, certifications, contracts and other details

- information on the diplomas issued

- data on the state-financed semesters (this is closely related to Hungarian State Scholarship, which finances individual studies under certain obligations)

- the study records of every student

Data collection is fully automated, as the central database updates itself every single night from the information provided by the institutional administration systems. Personal interaction is also involved, as the errors are listed at each night's data collection run, and the Education Authority's staff is checking the errors listed by the algorithms. FIR provides data for the Social Security Administration 
(Országos Egészségbiztositási Pénztár - OEP), which follows the health entitlements of university students.

Actual uses of the data are manifold:

- it can be used to provide information on other government organizations

- it produces statistics for the National Statistics Office and OECD

- it can provide information on the students' and lecturers' data

- it serves as the basis for the Evidence-based Management Information System (Adattár Alapú Vezetöi Információs Rendszer - AVIR)

\subsection{Patterns of performance measurement}

Most of our interlocutors have signaled their concerns with the production and use of evidence that is being produced in the higher-education system. Producing evidence has been a longstanding objective to the government as well as the institutions themselves. As Source 1D put it:

Gathering higher education data, as well as preparing and using them for policy decisions is at least a two decades old problem. In the 1998 World Bank development program a whole section was devoted to developing Management Information Systems, but the level of resistance from the institutions and the ministerial level was very high, topped by activities and motivations defined in the Penal Code. We are lagging behind a great deal even compared to ourselves. Everyone feels comfortable when things are managed by hand, so nobody should see any data. It is much easier to believe that it is up only to me to decide what will happen.

Most recently (from mid-2014) FIR has been linked with other data sources in other parts of the public administration. This involves the records of the National Tax and Customs Authority (NAV), which follows the personal income tax data of past students. This provides a robust set of data on the earnings (and earning premiums) of former students having graduated from different programs and institutions. This can be used to assess the real outcomes of higher education, as direct information is becoming available to judge, benchmark and measure the unemployment or employment patterns of graduates.

FIR (and its supplementary databases and data links) provide an exceptional tool to monitor the input (through Felvi.hu, the online higher education application procedure), the process (the individual progress of students and the resources allocated by the higher-education institutions themselves), outputs (number of diplomas issued) and outcomes (through the tax authority's data and other, mostly voluntary graduate and alumni surveys) of higher education. Data available in FIR is of high consistency and quality. 


\subsection{How are performance data used?}

Our interviewees identified three possible uses for the performance data produced in the FIR. The first is resource allocation to optimize the daily working processes within the Education Authority. Secondly, the FIR compiles data for the policymakers deciding on the allocation of state-sponsored students and per-capita grants for the HEIs. A third possible use is within the HEIs themselves, as they could analyze their own data and optimize their workings, if they want to.

Regarding the use of performance information each one of our sources (Sources $1 \mathrm{~A}, 1 \mathrm{~B}, 1 \mathrm{C}$ and $1 \mathrm{D}$ ) agrees that there is still a lot to be done in order to fully utilize the possibilities inherent in FIR. The more modest critics say that they still need time to get used to the system, to understand and interpret the data. This holds true for the HEIs, the policymakers and the public administration as well. According to our Source 1A, current users include the sectorial ministry:

The Ministry of Human Resources [the ministry responsible for higher education] is increasingly using the system, and the Education Authority is using it on a daily basis to fulfill its duties.

This optimist approach is not shared by other stakeholders. Source 1D articulated his serious criticism:

Data is available for the decision-makers, and most of the data is of high quality. They even know about the data. But the informed handling, the communication, the planning and the coordinating of data analysis is completely missing. There is no organization to fulfill this role, even though there was one try [from 2012 until 2014 a small team of analysts was put together in the Education Authority to fulfill this role, but their efforts were fruitless and their advice was not taken into account]. In the long run, there should be an organization which interprets hard data for policymakers... otherwise they will read them as they like.

However, Source 1B expressed cautious optimism:

We are moving in this direction [performance management]. FIR is becoming the base for decisions, in the near future universities will be funded completely on the basis of FIR data, making data input more important. The government is increasingly relying on the gathered data. At this moment the system is not perfect, but everything moves in this [increasing role of FIR] direction.

Obstacles are present in the utilization of FIR. The first concern is transparency, which is a very alien concept to Hungarian policy making, as Source 1A added: 
There are big debates and dramas, because everything became visible. A lot of room for maneuver, which was open before FIR came in, is now closed down, and several actors are not very happy about this. If HEIs see the data and can compare among each other, they become discontent. But for the university administration, FIR also serves as a motivation tool: they can compare themselves to other institutions, which can lead to pride too ... they wanted to do things better... As soon as the official statistics are produced by FIR, even the funding of HEIs will be based on this data. Of course, there is a manual 'correction' at the end, but the sector started to rely on this new source of data.

This possible financial use, as detailed by our interviewee at the Education Authority, is not shared by Source 1D, who states:

The use of any data can be extremely advantageous unless we fetishize data. This is clearly not a danger in Hungary, where the limited use of data is the gravest concern. Still, in a way we fetishize data at the same time, saying 'Let's close down all of the majors which are being taught parallel at 20 institutions.' We do not decide on personal careers only: we influence local communities, the local access to higher education, and maybe the whole scientific community. We cannot predict this from the hard data only. Still, a responsible leader cannot make a decision which is not supported by data ... I make my decision based on the market, but I do let market forces work. This is a prime example of evidence-based bad decisions... The point is that we do not use data because we do not understand them. But we do not understand management either, as the managers of higher education lack managerial skills.

\subsection{Conclusions and patterns}

If we put the previous evidence into the matrix developed earlier on the basis of the Bouckaert-Halligan model we will receive the following result (Table 2).

As Table 2 shows, performance management in higher education does not really fit any of Bouckaert and Halligan's ideal types. As for measurement, the system is very complex and sophisticated, mostly corresponding to the "management of performances" type. But for the most critical parts of performance management (with management being in the center of our focus), incorporation and use, we see a lesser level of development, with most results in the performance-administration category. 
Table 2

The projection of FIR on the four ideal types of performance management

\begin{tabular}{|c|c|c|c|}
\hline Ideal type features & $\begin{array}{c}\text { Performance } \\
\text { administration }\end{array}$ & $\begin{array}{l}\text { Management of } \\
\text { performances }\end{array}$ & $\begin{array}{c}\text { Performance } \\
\text { managemen } \\
\text { (it) }\end{array}$ \\
\hline \multicolumn{4}{|c|}{ Measurement } \\
\hline Type of measurement & $\checkmark$ & & \\
\hline Design of measurement system & & $\checkmark$ & \\
\hline Span of measurement & & $\checkmark$ & \\
\hline Depth of measurement & & $\checkmark$ & \\
\hline Criteria of indicators & & $\checkmark$ & \\
\hline $\begin{array}{l}\text { Specific dimension of } \\
\text { measurement }\end{array}$ & & $\checkmark$ & \\
\hline Dysfuncionalities of measuring & & & $\checkmark$ \\
\hline \multicolumn{4}{|c|}{ Incorporation } \\
\hline Level of incorporation & $\checkmark$ & & \\
\hline Degree of incorporation & $\checkmark$ & & \\
\hline \multicolumn{4}{|c|}{ Use } \\
\hline General use & & $\checkmark$ & \\
\hline Main reporting focus & $\checkmark$ & & \\
\hline Learning by using (standards) & $\checkmark$ & & \\
\hline Accountability of performance & $\checkmark$ & & \\
\hline $\begin{array}{l}\text { Potential value added of } \\
\text { performance }\end{array}$ & $\checkmark$ & & \\
\hline $\begin{array}{l}\text { Potential dysfunctions of } \\
\text { performance }\end{array}$ & & $\checkmark$ & \\
\hline
\end{tabular}

This result signals a significant potential for future development: the data is already there, able to measure input, process, outcome and effects (since students can be followed from the application up until they become pensioners decades from now), and higher-education institutions themselves will be able to monitor their own activities through the data uploaded to FIR. It will probably take a long time, however, until the policy-making community will learn how to use these tools for the better, and this is where the role of policy transfer can play a prominent role.

The case of the Education Authority can be portrayed as an exemplary case of performance administration. However, the use of performance information - as we will show later - is not well spread, which is in a stark contrast to the efforts that have been put into organizing and maintaining the records.

Regarding the ownership (as defined per van Dooren et al. 2010, 181) of the PM system and the question of "who has the power to measure" we have to note that the opportunity to use performance information is present on every level, from 
the higher-education institution up to the sectoral ministry, as data is available for everyone (naturally with different levels of access). The decision to use performance information rests with the managers of the individual levels, and they are becoming more and more conscious of this opportunity (as told by Source 1B). The feeling of data-ownership seems to support the spreading of PM methods in the highereducation sector.

\section{Case 2: Local governments - performance management on the rise}

\subsection{Background}

In terms of its local-government system Hungary can be classified, according to Kuhlmann and Wollmann's typology (2014, 90ff.), as a Central Eastern European Model. Hungary's local-governmental system is structured in two tiers: counties and municipalities (területi and települési) (Magyarország Alaptörvénye - The Basic Law of Hungary). The upper tier is composed of nineteen counties and the capital city Budapest. The lower tier, the municipality-level local governments, is composed of communes, towns, cities and districts, making up 3154 local governments in total (National Statistics Office 2014).

The local government setting underwent significant and abrupt changes since 2010 (see Hajnal and Rosta 2014 and Hajnal 2014 for details). Public-administration reforms on the subnational level included:

- assumption of key local public services (schools, hospitals) and administrative functions from local self-governments to central agencies;

- establishment of a new hierarchy of centrally controlled territorial administrative structures, the County Government Offices and (lower level) District Government Offices;

- centralization (takeover) of a broad range of administrative-service provision from local governments to District Government Offices;

- centralization of regional development institutions;

- transferring a broad range of local- and county-level public-service institutions and tasks (such as secondary and primary schooling, secondary health-care institutions) from self-governments to central-government agencies;

- nationalization of public utility companies (both from local governments and foreign companies);

- compulsory amalgamation of local-government offices (in municipalities smaller than 2000 people);

- radical transformation and decrease of local-government funding and borrowing; 
- cutting public utility fees by means of stringent price and service regulations.

The compulsory tasks of LGs are regulated in Law 189/2011 on the local governments. The tasks are clearly set out in a comprehensive list, provided by the Law, and include - among others - local development, providing basic health care, kindergarten services, providing cultural services, financing local welfare spending, local environmental protection, organizing local transport, solid waste disposal, providing water utilities and many others.

Currently LGs operate out of government transfers and local incomes. The Parliament annually decides on the amount of the total central support for LGs. Nationally, approximately $80 \%$ of total LG incomes are from central transfers. If an LG runs out of money, it can receive additional funds, as detailed by the 39/2013 (VII. 31.) Ministry of the Interior Decree. In this case, LGs must apply for the minister responsible for LGs, who establishes a committee, and this committee decides whether the LG will receive additional funds.

The funding reform, which was initiated in 2010 and came into effect in 2013, provided a very rigid, expenditure-oriented framework. This, combined with the decrease of the available funds (as many previously LG-organized public services were centralized) restricted the economic room for maneuver of the LGs. The financing system is not well-developed at the moment, which leads to inflexibility at the local level. LGs are not motivated to raise extra funds, as they are not able to use them as they see fit, and LGs increasingly need to adapt to the central government's priorities in order to gain extra (mostly EU) funds. The program-based budgeting method is supposed to lead to better allocation mechanisms in funding public services, and a simpler system would promote transparency (Mezei 2014, 3-4)

\subsection{Patterns of performance measurement}

Finding even relatively stable patterns of performance management in Hungarian local governments is not an easy task: the legal/regulatory and institutional environment has been dynamically changing since 2010 , with far-reaching centralization efforts on the central government's side (for details see Hajnal 2014 and Hajnal and Rosta 2014). Previously, local governments had a wide range of autonomy and some liberty in organizing the funding for obligatory and elective public services.

External pressures - such as the central government's continuous legislative reforms as well as the radical decrease of available funds - directed the attention of local governments to using their funds efficiently. As Source $2 \mathrm{~F}$ put it,

There is measurement of LG activities' efficiency and speed as well as assessments of outcomes and regulations' impacts. It is important how many people complete which assignments with what costs, how much we spend on public park maintenance for instance. Where efficiency really matters is the sphere of compul- 
sory public services, like providing drinking water, or managing public cemeteries.

This view is supported by our local contacts in Eger.

Because of the various compulsory tasks and the lack of appropriate funding, performance management is gaining ground in the field of public services. As Source $2 \mathrm{G}$ vividly put it:

In the field of public services we see a demand for performance management, and even for establishing a benchmarking system. But even a system in which the central government provides funds for individual tasks does not provide normative financing, nobody knows what each task costs, and nobody can benchmark these data against the results of other LGs [because clear definitions are lacking, therefore benchmarking is not possible].

But the need for performance management on the LGs' side is clearly there: all of our interviewees underscored the importance of measurement, benchmarking and efficiency.

Even the understanding of performance management is unstructured (when asked whether PM exists in Eger, Source 2B said, "no, it does not exist", but a few minutes later it turned out that the company operates on the basis of performance contracting and measures most of its activities, even though in the form of fiscal reporting). The local government of Eger decided to establish a non-profit, LG-owned company to complete the obligatory tasks, which are set out in the Law on Local Governments. This company, "Városgondozás Eger Nonprofit Kft" is owned 100 percent by the LG of Eger and works on the basis of a yearly performance contract concluded between the town and the company. The performance contract states the works and services required by the municipality and assigns funds based on the unit price of each task.

Because the prices are fixed, efficiency becomes increasingly important. Source $2 \mathrm{~A}$ concedes that

the central government transfers are intended to cover average costs, and whoever cannot provide the same services for the given price will be below average in the national comparison. This could be useful for comparison, if the central government made some calculations. Furthermore, on the central level there are no incentives to become more efficient, to raise output and make our processes better.

This holds true on the level of the public-services company, based on the opinion of Source 2B: 
Our tasks are measurable, mostly connected to a unit price and the wage of the workers. We know the tasks, the performance criteria (for instance the height of the grass in different city locations), and we also know the work phases. We must know how many people and resources and how much gasoline and time is needed to complete each of our tasks.

So the prerequisites for the appearance of performance management are clearly present in our case, as input data is usually recorded. This includes how many people are working on different tasks, how much money is used, what time is needed to complete the tasks, etc. Sometimes even the results are measured, when the managers go out to observe and control the work that was done, measure the height of the grass, etc. Controlling is an integral part of the service contract, and the LG puts special emphasis on checking the (visible) results of Városgondozás Eger.

Most of the measurement is concentrated around financial issues and accounting. Regarding the use of this data, Source 2B continued:

There is no bad data, just bad evaluation. We have scores of information, but there is no system. We would benefit from the use of information. Habits are hard to break: people still think they are working for a state-owned company, they get their salaries regardless of whether the job is done. But money is not the only tool for measurement, even though we are measured with it: every day costs money.

By this he meant that even though data is already present at the company, currently there is no systematic way to organize it for further use. The company already measures several processes (like grass-cutting, tree- and flower-planting, cleaning roads and repairing benches, for example), but data is very hard to access, and the human capacity to analyze it is missing.

When we talked to local-government officials and the workers of Városgondozás Eger, the main concern was money: how to maintain or even raise service levels with decreasing funds. Measurement is concentrated on money spent instead of outcomes.

\subsection{How are performance data used?}

When asked about the use of performance information, our sources gave answers differing according to their management role. Source $2 \mathrm{~A}$ identified several areas where data is:

we have to make the town financially sustainable. The law does not state how to fulfill obligatory tasks, I have to find it out, I have to decide what criteria I will use when I cut back funds, 
or reassign responsibilities. We also have to reason if we want a change in the law, and we need data to do that ... If we do not measure, we cannot explain to the citizens why we are doing what we are doing. This can affect citizen satisfaction and the perception of the people... We have to educate people so they know that local services do not appear out of the blue. People do not care about the cost of lighting the town, even though they pay for it. Our job is to orientate the thinking of the citizens, and we need information to do that.

As we approach the lower levels (the senior management and mid-level management of Városgondozás Eger), the possible use of measurement narrows down to financial matters.

We have to make sure we use our human and material resources effectively,

says Source $2 \mathrm{~B}$,

how we would maintain the same service level with less funds.

Source $2 \mathrm{C}$ reinforces this fiscal perspective:

practical information is very important: for instance we could set benchmarks for our personnel which they should meet to get a good personal evaluation. We must finish our job as soon as possible.

Performance administration is gaining ground in Eger, as financial reporting is well-established and applied. The works completed by the individual service units are logged, and this serves as the basis for data being reported to the senior management and the town leaders.

Even though there is a clear need on the mayor's part to use data, to inform and educate citizens, the data that are so badly needed fail to materialize. Not because the lower tiers would not like it, but because of the lack of capacities in the staff.

We should resort to outside consultants, we do not have enough time and expertise to develop our own measurement system, says Source $2 \mathrm{~B}$.

The best way to measure is to translate tasks to money,

he concludes, which is justifiable from his point of view, but clearly misses the demands of the mayor. 


\subsection{Conclusions and patterns}

What is clearly visible from our data is that even an LG which is working hard to introduce performance management has a very vague concept of PM. When we asked our interviewees the standard question "does performance management exist in your organization?", they answered with a definite "no" or "I do not know". However as we translated the concept of PM to fit their own perceptions, it turned out they are already using some methods that resemble the manifestations of performance management. The already existing instances of PM ideas and methods in Eger were in contrast to the unawareness of the whole concept of performance management as it is conceptualized in academic literature. We summarize our data in Table 3. In this table, we have added one additional category, the pre-performance stage, as some of our observations only fit this category.

Table 3

Summary of the findings of the LG Case adapted to the ideal types

\begin{tabular}{|c|c|c|c|c|}
\hline Ideal type features & 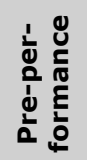 & 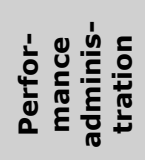 & 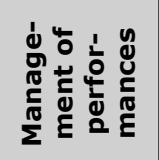 & 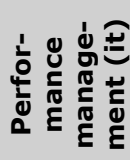 \\
\hline \multicolumn{5}{|c|}{ Measurement } \\
\hline Type of measurement & & $\checkmark$ & & \\
\hline Design of measurement system & & $\checkmark$ & & \\
\hline Span of measurement & & $\checkmark$ & & \\
\hline Depth of measurement & & $\checkmark$ & & \\
\hline Criteria of indicators & & $\checkmark$ & & \\
\hline Specific dimension of measurement & $\checkmark$ & & & \\
\hline Dysfuncionalities of measuring & & $\checkmark$ & & \\
\hline \multicolumn{5}{|c|}{ Incorporation } \\
\hline Level of incorporation & $\checkmark$ & & & \\
\hline Degree of incorporation & & $\checkmark$ & & \\
\hline \multicolumn{5}{|c|}{ Use } \\
\hline General use & & $\checkmark$ & & \\
\hline Main reporting focus & & $\checkmark$ & & \\
\hline Learning by using (standards) & $\checkmark$ & & & \\
\hline Accountability of performance & & $\checkmark$ & & \\
\hline $\begin{array}{l}\text { Potential value added of } \\
\text { performance }\end{array}$ & $\checkmark$ & & & \\
\hline $\begin{array}{l}\text { Potential dysfunctions of } \\
\text { performance }\end{array}$ & $\checkmark$ & & & \\
\hline
\end{tabular}


The LG of Eger is in a very initial stage of performance management, even though the desire to use and produce performance data is clearly visible. Policy learning already serves as a way to add PM tools to the LGs' inventories. LGs (and the LG of Eger) is trying to save money by making their work more effective. The scarcity of funds is perceived as a major coercive force behind the need for performance/management measures. Two respondents told us that they do not plan to adopt PM methods, because it is too costly (even though they conceded they did not know what PM methods actually mean).

Ownership of data and understanding PM methods were raised as pressing questions during the interviews. The higher we got in the administration, the more elaborate was the concept of using performance information, and the stronger the sense of ownership became. On the lower (mid-managerial) levels, ownership was not expressed, and PM was mostly seen as another tasks which was received from "somewhere higher"; therefore the possibilities in PM were not fully embraced.

\section{Discussion}

PM as a concept is poorly conceptualized in Hungary, yet the actual instances of PM are clearly visible across the different cases. The two cases are similar in several respects: the cultural, administrative and legislative setting is the same, just as the outside budgetary pressure and the possible sources of data. Performance-management practices are spreading in both organizations.

The initial proposition of the policy-transfer literature is that more transfers lead to better policies, as the core concept of transfer is to find better solutions to existing problems. In both cases we see an expressed desire to introduce PM practices for the very same goal: making work more effective. However, our data show that policy transfer alone is not enough to trigger change. It can be a facilitating factor, a source of ideas, but even what is perceived as "coercive transfer" does not make a recognizable effect on the ground (as we have seen in the World Bank program's initial failure). Both cases underline the disconnected development structure of PM in Hungary. Academic knowledge is scarce, but indigenous innovation is one of the key features in PM-development. Most of the PM activities are still concentrating on the fiscal reporting perspective, but attempts are being made to use performance information and incorporate it into decision-making. Significant progress was made in this regard, unaware of the international theoretical discourse.

As for the sources of PM techniques in Case 1 we can see that policy transfer did not play a significant role, as this was present only at the inception of the original idea (that MIS should exist, see World Bank 1998). In Case 2, domestic sources are more important. Most of the best practices mentioned by our LG sources are not from abroad; rather they are taken over from other Hungarian LGs. The importance of domestic policy transfer was mentioned by every single LG source, and this 
signals that national-level policy transfer, where similar(ly challenged) organizations (local governments, utility companies, etc.) are learning from each other, are equally important and diverse as the patterns of international policy transfer. This internal push can overcome even the hindrances rooted in the Hungarian legislative tradition, which works against PM-like innovations.

Bouckaert and Halligan's ideal type framework was adaptable to the Central and Eastern European country model of Kuhlmann and Wollmann, which shows the strength of this model, and that performance management can exist even under highly formalized and traditional Rechtsstaat conditions. However, the Hungarian PM pattern does not correspond to the original ideal-type features, as it is rather a mosaic of different features from different ideal types, pointing to the incremental and disconnected development process of PM practices. We would like to suggest that even though the original framework is a good tool to examine the development of PM-regimes in different countries, the ideal types do not necessarily correspond to actual data from the ground. We would not like to suggest that there is an ideal PM ideal type for the Rechtsstaat-environment, as this is not supported by our data, but that most ideal-type features can be found in Hungary; therefore the development of PM is not restricted per se by the administrative tradition, but can overcome historical and administrative barriers to shape and modernize Hungarian public institutions.

Another observation is connected to the supposed incremental development concept of PM regimes by Bouckaert and Halligan. We have seen that some elements of performance management have evolved to a much higher standard than other elements, and the system is actually working. In the case of FIR, measurement is of a very high standard, but the incorporation and use of data is lagging behind. Development was not sequential: the new FIR evolved directly (and according to our sources) to the "management of performances" ideal type, while use and incorporation did not follow. Users still have to learn and understand the complex set of data that became available recently.

In the case of local governments, our findings did not support the sequential development model either. Several elements (especially in measurement) reached a higher level of sophistication, while the use of available data lags behind. Instances of performance management remain sporadic and unconscious, and this lack of systematic application might make the use of existing categories complicated. This finding supports the results of Turc et al. (2014), who argue that the "sense of progression" implied by Bouckaert and Halligan is contradictory.

Further research is needed to see what the crucial factors are when performance-management tools are introduced into Hungarian governance. Two promising tracks for further research could be the role of accountability and the ownership of data. We established that different PM tools are already present, albeit not in a systematic way. Further research could identify whether the personal influence 
of leaders, different management methods or other factors are responsible for this pattern, to what extent can we observe international and domestic policy transfer and whether the ownership of PM data and the democratization of the right to measure promotes the spreading of different PM-practices, even in an inhospitable Rechtsstaat-environment.

\section{References}

Bartlett, W. 2013. "Obstacles to Evidence-Based Policy Making in the EU Enlargement Countries: The Case of Skills Policies." Social Policy and Innovation 47(4), 451-467.

Bouckaert, G. and J. Halligan. 2008. Managing Performance: International Comparisons. New York: Routledge.

Clarke, A. E. 1991. "Social Worlds/Arenas Theory as Organizational Theory." In D. R. Maines (ed.). Social Organization and Social Process: Essays in the Honor of Anselm Strauss. New York: Aldine de Gruyter, 119-158.

Hajnal, G. 2014. "Unorthodoxy at Work: An Assessment of Hungary's post-2010 Governance Reforms." Paper presented at the IRSPM $18^{\text {th }}$ Annual Conference. Available at http://www.researchgate.net/publication/273447223_UNORTHODOXY_AT_WORK_AN_ASSESSMENT_OF_HUNGARY\%27S_POST2010_GOVERNANCE_REFORMS (last accessed 21 June, 2015DATE).

Hajnal, G. 2006. "Kultúra és teljesítmény a közigazgatásban" [Culture and performance in public administration]. Vezetéstudomány 37(4), 2-9.

Hajnal, G. 2003. "Hopes and Reality: The First Decade of the Hungarian Local Government System in the Eyes of the Public." In P. Swianiewicz (ed.). Public Perception of Local Governments. $2^{\text {nd }}$ edn. Budapest: OSI/LGI, 115-168.

Hajnal, G. and G. Gajduschek. 2010. Közpolitika. Budapest: HVG-Orac.

Hajnal, G. and G. Jenei. 2008. "The Study of Public Management in Hungary: Management and the Transition to Democratic Rechtsstaat." In W. J. M. Kickert (ed.). The Study of Public Management in Europe and the United States: A Comparative Analysis of National Distinctiveness. London: Routledge, $208-232$.

Hajnal, G. and M. Rosta. 2014. "The Illiberal State on the Local Level: The Doctrinal Foundations of Subnational Governance Reforms in Hungary (2010-2014)." Paper presented at the EGPA Annual Conference, 10-12 September 2014, Speyer, Germany. EGPA-PSG V/COST-Action IS1207. Available at http:// www.researchgate.net/publication/273887891_The_illiberal_state_on_the_ local_level_The_doctrinal_foundations_of_subnational_governance_reforms_in_Hungary_\%2820102014\%29 (last accessed 17 May 2015). 
Hajnal, G. and M. Ugrósdy. 2015. "Performance Management Reform as Policy Transfer: The Case of Hungarian Local Government." Conference Presentation at the Trans-European Dialogue in Public Administration/TED8, 5-6 February 2015, Milan, Italy.

Közigazgatási és Igazságügyi Minisztérium (KIM). 2012. Magyary Zoltán Közigazgatás-fejlesztési Program 12.0. Available via KIM at http://magyaryprogram. kormany.hu/admin/download/d/2c/40000/Magyary\%20kozig\%20fejlesztesi\%20program\%202012\%20A4.pdf (last accessed 17 May 2015).

Kuhlmann, S. and H. Wollmann. 2014. Introduction to Comparative Public Administration. Cheltenham: Edward Elgar.

Mezei, C. (ed.). 2014. Zárótanulmány a hazai önkormányzatok finanszírozási helyzetéröl. Pécs: MTA KRTK.

National Statistics Office. 2014. Statistical Yearbook of Hungary. Budapest: KSH.

Nemec, J. and V. Sagat. 2011. "Performance Management in CEE: What can we Learn from Existing Experience?" Paper presented at the 2011 ECPR General Conference in Reykjavík, Iceland, 25-27 August 2011. Available at http:// ecpr.eu/filestore/paperproposal/17d7a451-c55e-4c84-8c64-22c4e7cb547c. pdf (last accessed 30 June 2015).

Staronova, K. 2009. "Better Regulation and Regulatory Quality: The Case of RIA in Slovakia." Sociológia 41(3), 247-264.

Staronova, K. 2006. The Public Policy Process: Implementation of the Recommendations from the Analysis of the Policy Making Process in Slovakia. Budapest: Central European University/Open Society Foundation.

Staronova, K. 2005. Public Policy-Making in Slovakia. Bratislava: Slovak Governance Institute.

Staronova, K. and G. Gajduschek. 2013. "Civil Service Reform in Slovakia and Hungary: The Road to Professionalization?" In C. Neuhold, S. Vanhoonacker and L. Verhey. Civil Servants and Politics: A Delicate Balance. New York: Palgrave Macmillan. 123-145 https://www.psa.ac.uk/sites/default/files/279_178.pdf (Last accessed November 2, 2015).

Turc, E., M. Guenoun, M. A. Rodrigues et al. 2014. "Performance Management and Measurement in Local Governments of the Napoleonic Administrative System: A Comparative Analysis of France, Portugal, and Turkey." Paper presented at the 2014 Annual conference of the European Group of Public Administration (EGPA), Speyer (Germany).

van Dooren, W., G. Bouckaert and J. Halligan. 2010. Performance Management in the Public Sector. London: Routledge. 
The NiSPAcee Journal of Public Administration and Policy, Vol. VIII, No. 2, Winter 2015/2016

World Bank. 1998. Staff Appraisal Report Republic of Hungary: Higher Education Reform Project. Washington, DC: World Bank.

Yin, R. K. 2009. Case Study Research, Design and Methods. $4^{\text {th }}$ edn. London: Sage. 